\begin{tabular}{|c|c|c|c|c|}
\hline JURNAL & \multirow{2}{*}{ NOMOR 1 } & HALAMAN 51-64 & $\begin{array}{l}\text { ISSN 2655-8823 }(p) \\
\text { ISSN 2656-1786 }(e)\end{array}$ \\
\hline
\end{tabular}

\title{
DAMPAK PENGANGGURAN TERHADAP TINDAKAN KRIMINAL DITINJAU DARI PERSPEKTIF KONFLIK
}

\author{
Rafli Muhammad Sabiq \\ Prodi Ilmu Kesejahteraan Sosial FISIP Universitas Padjadjaran \\ E-mail: rafli19002@mail.unpad.ac.id \\ Nurliana Cipta Apsari \\ Pusat Studi CSR, Kewirausahaan Sosial dan Pemberdayaan Masyarakat FISIP Universitas Padjadjaran \\ E-mail: nurliana.cipta.apsari@unpad.ac.id
}

\begin{abstract}
ABSTRAK
Pekerjaan memiliki peran penting dalam keberlangsungan hidup masyarakat. Masyarakat tentu ingin mendapatkan pekerjaan sebaik-baiknya untuk kehidupan yang baik dan terhindar dari pengangguran. Pengangguran menjadi masalah sosial yang belum terselesaikan dan menjadi mimpi buruk bagi masyarakat. Pengangguran dapat menyebabkan masalah bagi yang mengalaminya seperti depresi dan menyebabkan masalah sosial lainnya seperti tindakan kriminal. Pengangguran sering menjadi alasan bagi seseorang untuk melakukan tindakan kriminal demi memenuhi kebutuhannya. Penelitian ini bertujuan untuk menjelaskan faktor penyebab dan dampak dari pengangguran yang dapat menyebabkan tindakan kriminal. Hal ini selanjutnya akan ditinjau menggunakan perspektif konflik yang mencakup sejumlah teori dan fokus yang menjelaskan tentang adanya ketidaksetaraan, dominasi, kekuatan, dan ketimpangan yang terjadi dalam kehidupan masyarakat. Hasil penelitian menunjukkan bahwa pengangguran memberikan tekanan psikologis bagi para penganggur yang dapat menyebabkan terjadinya tindakan kriminal. Tekanan ini membuat para penganggur tidak dapat berpikir jernih dan membuatnya menghalalkan segala cara termasuk tindakan kriminal demi memenuhi kebutuhan-kebutuhannya.
\end{abstract}

Kata kunci: pengangguran, kriminal, perspektif konflik, ketimpangan, dominasi.

\section{PENDAHULUAN}

Manusia dilahirkan di dunia oleh Tuhan YME untuk menjadi seorang pemimpin di bumi. Salah satu misi dari manusia adalah memakmurkan dunia dengan segala upaya dan kemampuan yang dimiliki. Manusia memiliki banyak kebutuhan dalam melakukan aktivitas sehari-hari. Terdapat banyak faktor yang dibutuhkan manusia untuk melanjutkan keberlangsungan hidup. Faktor tersebut seperti yang kita ketahui disebut dengan kebutuhan. Kebutuhan adalah keinginan manusia terhadap sesuatu baik barang maupun jasa dalam usahanya untuk mempertahankan kehidupan di mana pemuasannya dapat bersifat jasmani dan rohani. Dengan kebutuhan manusia yang tak terbatas, terciptalah kegiatan ekonomi (Gunawijaya, 2017). Menurut Gunawijaya (2017) ekonomi merupakan aktivitas kegiatan manusia di muka bumi ini, sehingga kemudian timbul motif ekonomi, yaitu keinginan seseorang untuk dapat memenuhi kebutuhan hidupnya. Setiap manusia ingin mendapatkan pekerjaan karena dengan bekerja ia mengharapkan mendapat imbalan untuk memenuhi kebutuhan hidupnya (Budiarti, 2015). Sayangnya, jumlah pekerjaan yang tersedia tidak sebanding dengan jumlah manusia yang membutuhkan pekerjaan. Manusia yang tidak memiliki pekerjaan, akhirnya menjadi seorang pengangguran.

Menurut Badan Pusat Statistik, tercatat bahwa jumlah angkatan kerja pada Februari 2020 sebanyak 137,91 juta orang, naik 1,73 juta orang dibanding Februari 2019. Dalam setahun terakhir, pengangguran bertambah 60 ribu orang, berbeda dengan Tingkat Pengangguran Terbuka (TPT) yang turun menjadi 4,99 persen pada Februari 2020. Penduduk yang bekerja sebanyak 131,03 juta orang, bertambah 1,67 juta orang dari Februari 2019. Lapangan pekerjaan yang mengalami peningkatan persentase terutama jasa pendidikan $(0,24$ persen 


\begin{tabular}{|c|c|c|c|c|}
\hline JURNAL & \multirow{2}{*}{ VOLUME 3} & \multirow{2}{*}{ NOMOR 1 } & HALAMAN 51-64 & $\begin{array}{l}\text { ISSN 2655-8823 }(p) \\
\text { ISSN 2656-1786 (e) }\end{array}$ \\
\hline
\end{tabular}

poin), konstruksi (0,19 persen poin), dan jasa kesehatan (0,13 persen poin). Sementara lapangan pekerjaan yang mengalami penurunan terutama pada pertanian $(0,42$ persen poin), perdagangan $(0,29$ persen poin), dan jasa lainnya $(0,21$ persen poin). Persentase tertinggi pekerja pada Februari 2020 adalah pekerja penuh (jam kerja minimal 35 jam per minggu) sebesar 69,90 persen. Sementara itu, pekerja tidak penuh terbagi menjadi dua, yaitu pekerja paruh waktu (23,74 persen) dan pekerja setengah penganggur $(6,36$ persen). Dalam setahun terakhir, persentase pekerja setengah penganggur turun sebesar 1,01 persen poin, sedangkan persentase pekerja paruh waktu meningkat sebesar 1,07 persen poin. Menurut data tersebut, tercatat bahwa tingkat pengangguran semakin menurun dalam setahun terakhir. Namun, data tersebut menunjukan bahwa tingkat pengangguran masih relatif tinggi.

Pengangguran merupakan istilah untuk orang yang tidak bekerja sama sekali, sedang mencari pekerjaan, atau seseorang yang sedang berusaha untuk mendapatkan pekerjaan yang layak. Menurut Sukirno (dalam Probosiwi, 2016) pengangguran adalah seseorang yang sudah digolongkan dalam angkatan kerja yang secara aktif sedang mencari pekerjaan pada suatu tingkat upah tertentu, tetapi tidak dapat memperoleh pekerjaan yang diinginkan. Secara umum, pengangguran disebabkan oleh ketimpangan antara jumlah pekerjaan yang tersedia atau lapangan kerja tidak sebanding dengan jumlah angkatan kerja atau para pencari kerja (Basrowi, et.al, 2018). Anata (2013) dan Rahmalia et.al. (2019) berpendapat bahwa ketimpangan ini dapat berdampak kepada kondisi ekonomi dan kehidupan bermasyarakat yang menimbulkan ketidakstabilan politik dan sosial.

Pengangguran menjadi beban psikis dan psikologis seperti tekanan emosi dan pikiran yang tidak stabil bagi yang menganggur dan keluarganya (Ikawati, 2019). Ikawati mengatakan bahwa para penganggur akan memiliki perasaan tidak enak dengan keluarga dan lingkungannya, ada perasaan malu, serba salah, beban moral, merasa tidak berguna, kurang percaya diri, mudah tersinggung, dan tertekan karena tuntutan orang tua dan keluarga. Para penganggur akan melakukan berbagai cara untuk mendapatkan pekerjaan dan memenuhi kebutuhan hidupnya. Namun, tidak sedikit dari para pengangguran yang akhirnya melakukan tindakan-tindakan yang melanggar norma dan hukum demi memenuhi kebutuhan hidupnya, seperti tindakan kejahatan atau kriminalitas.

Ismah (2015) dalam penelitiannya yang berjudul "Pengaruh Pengangguran terhadap Kriminalitas di Kabupaten Solok" menyatakan bahwa pengangguran dan kurangnya pendapatan yang diperoleh untuk memenuhi kebutuhan sehari-hari dapat membuat seseorang malas bekerja sehingga lebih memilih jalan pintas untuk mendapatkan uang. Keadaan menganggur dan pendapatan yang kurang dapat membuat seseorang berpikir untuk melakukan tindakan kriminal. Banyaknya pengangguran akan berpengaruh terhadap produktivitas dan pendapatan masyarakat sehingga dapat menyebabkan masalah sosial seperti kriminalitas.

Kriminalitas secara harfiah berasal dari kata crimen yang artinya kejahatan, tindak kriminal, atau juga diartikan suatu tindakan kejahatan, sehingga merupakan tindakan yang bersifat negatif (Khairani, et.al, 2019). Tindakan ini akan merugikan banyak pihak dan pelaku tindakannya disebut sebagai seorang kriminal. Sederhananya, kriminalitas merupakan segala tindakan atau sesuatu yang dilakukan individu, kelompok, maupun komunitas yang melanggar hukum atau suatu tindakan kejahatan, yang mengganggu keseimbangan atau stabilitas sosial dalam masyarakat (Sari, 2019). Krisis ekonomi, kemiskinan, pengangguran, dan kesenjangan sosial merupakan beberapa faktor yang sering memicu terjadinya tindakan kriminal. 


\begin{tabular}{|c|c|c|c|c|}
\hline JURNAL & \multirow{2}{*}{ VOLUME 3 } & \multirow{2}{*}{ NOMOR 1 } & HALAMAN 51-64 & $\begin{array}{l}\text { ISSN 2655-8823 }(p) \\
\text { ISSN 2656-1786 }(e)\end{array}$ \\
KOLABORASI RESOLUSI KONFLIK & VOMS \\
\hline
\end{tabular}

Menurut Nadilla (2018) kriminalitas merupakan suatu masalah sosial yang harus diberantas agar tingkat keselamatan masyarakat dapat meningkat secara berkelanjutan. Dari segi faktor ekonomi, tindakan kriminal dapat terjadi karena kecukupan masyarakat dalam berkegiatan sehari-hari tidak mampu meningkatkan kesejahteraannya (Nadilla, 2018). Oleh karena itu, tidak sedikit masyarakat yang mencari jalan pintas dengan melakukan tindakan kriminal dengan harapan mampu meningkatkan kesejahteraan dirinya. Seorang filsuf bernama Cicero mengatakan "Ubi Societas, Ibi Ius, Ibi Crime" yang artinya dimana ada masyarakat, maka ada hukum dan ada kejahatan (dalam Shahar, 2018).

Pengangguran dan kriminalitas membutuhkan perhatian lebih dari para penangan masalah sosial seperti pekerja sosial. Pekerja sosial adalah orang yang membantu individu, kelompok, dan masyarakat yang mengalami masalah sosial (Asdar, et.al, 2020). Pekerja sosial memiliki berbagai peran dalam membantu masyarakat dan menangani masalah sosial, karena pekerja sosial merupakan unsur organisasi yang bersentuhan langsung dengan klien atau masyarakat. Menurut Dorang Luhpuri dkk (dalam Hidayah, 2016) terdapat tujuh peran yang dapat dilakukan oleh pekerja sosial, namun hanya empat peran pekerja sosial yang dapat dikaji lebih lanjut dalam menangani masalah pengangguran yang berdampak terhadap tindakan kriminal. Peran pekerja sosial tersebut antara lain adalah sebagai pembimbing sosial kelompok, penghubung atau broker, fasilitator, dan konselor atau counselor.

Sebagai pembimbing sosial kelompok, pekerja sosial mampu memberikan intervensi kepada masyarakat yang berkumpul melalui pertemuan yang teratur dan kegiatan yang disusun untuk mencapai tujuan yang telah disusun bersama. Sebagai penghubung (broker), pekerja sosial mampu menghubungkan masyarakat dengan lembaga terkait, maupun penghubung antara masyarakat dengan sumber lain yang dapat membantu dalam upaya pemecahan masalah masyarakat. Sebagai fasilitator, pekerja sosial mampu memberikan kesempatan atau fasilitas yang dibutuhkan masyarakat untuk memecahkan masalahnya, memenuhi kebutuhannya, dan mengembangkan potensi yang dimilikinya dengan cara memberikan dukungan emosional yang dibutuhkan masyarakat agar masyarakat merasa diperhatikan dan terpenuhi kebutuhannya. Terakhir, sebagai konselor (counselor) pekerja sosial mampu memberikan layanan konsultasi kepada masyarakat yang ingin mengungkapkan masalahnya agar masyarakat merasa didengarkan dan masalah yang dihadapinya dapat dimengerti.

\section{TINJAUAN PUSTAKA \\ Perspektif Konflik}

Perspektif konflik atau lebih dikenal sebagai teori konflik adalah teori yang memandang bahwa perubahan sosial tidak terjadi melalui proses penyesuaian nilainilai yang membawa perubahan, tetapi terjadi akibat adanya konflik yang menghasilkan kompromi-kompromi yang berbeda dengan kondisi semula (Tualeka, 2017). Teori ini didasari oleh kepemilikan sarana-sarana produksi sebagai unsur pokok pemisahan kelas dalam masyarakat. Pada abad ke- 19, Karl Marx (dalam Tualeka, 2017) menjelaskan bahwa masyarakat terdiri dari kelas pemilik modal (borjuis) dan kelas pekerja miskin (proletar). Kaum borjuis melakukan eksploitasi terhadap kaum proletar dalam proses produksi yang terus berjalan selama kesadaran semu eksis dalam diri proletar (rasa menyerah diri, menerima keadaan apa adanya) tetap terjaga.

Teori konflik memiliki gagasan bahwa setiap masyarakat pasti pernah mengalami konflik-konflik atau keteganganketegangan dan pertikaian dalam sistem sosial. Teori konflik berfokus pada dominasi, koersi, kekuasaan dalam masyarakat, dan otoritas yang berbedabeda. Otoritas yang berbeda-beda ini 


\begin{tabular}{|c|c|c|c|c|}
\hline JURNAL & \multirow{2}{*}{ VOLUME 3} & \multirow{2}{*}{ NOMOR 1 } & HALAMAN 51-64 & $\begin{array}{l}\text { ISSN 2655-8823 }(p) \\
\text { ISSN 2656-1786 (e) }\end{array}$ \\
KOLABORASI RESOLUSI KONFLIK & VOLA
\end{tabular}

akhirnya menghasilkan superordinasi dan subordinasi yang menimbulkan konflik karena adanya perbedaan kepentingan. Menurut teori konflik, konflik dibutuhkan untuk menciptakan perubahan sosial dengan masyarakat yang mencapai suatu kesepakatan bersama agar tercipta suatu konsensus. Menurut teori ini, keteraturan yang ada dalam masyarakat terjadi karena adanya paksaan atau koersi yang lekat dengan dominasi dan kekuatan (Tualeka, 2017).

Dalam Tumengkol (2012) dan Tualeka (2017) disebutkan bahwa salah satu pencetus perspektif konflik adalah Karl Marx. Ia memandang pertentangan dan eksploitasi kelas sebagai penggerak utama kekuatan-kekuatan dalam sejarah. Perspektif konflik melihat masyarakat konflik di antara kelas, di mana masyarakat terikat secara bersama karena kekuatan dari kelompok atau kelas yang dominan. Dasar dari perspektif konflik yang dijelaskan oleh Karl Marx, adalah sistem kapitalis menyebabkan ketidakadilan kaum pekerja yang dieksploitasi oleh kaum kapitalis, mereka dibayar dengan upah yang kecil dengan jam kerja yang tinggi. Hal ini dilakukan untuk memperoleh keuntungan kaum dominan atau kapitalis yang tinggi. Dalam sistem tersebut bauk kaum dominan dan pekerja tidak sadar akan ketidakadilan yang terjadi, tetapi menurut Karl Marx pekerja bisa mengenali eksploitasi dan mencapai kesadaran kelas. sederhananya, konflik yang terjadi dalam masyarakat disebabkan karena adanya interaksi sosial yang telah dipengaruhi oleh struktur sosial dan terdapat kepentingan-kepentingan kelompok masing-masing didalamnya serta didominasi oleh pengaruh-pengaruh lain seperti ekonomi, sosial, politik dan sebagainya. Konflik memang tidak terpisahkan dalam kehidupan masyarakat. Disisi lain, keberadaan konflik memang seharusnya ada, guna membangun kesatuan yang lebih kokoh dalam suatu kelompok.

Tualeka (2017) mengatakan bahwa terdapat beberapa teori-teori utama mengenai sebab-sebab konflik sebagai berikut:

\section{Teori Kebutuhan Manusia}

Teori ini beranggapan bahwa konflik yang terjadi disebabkan oleh kebutuhan dasar setiap manusia yang tidak terpenuhi atau terhalangi. Kebutuhan tersebut dapat berupa kebutuhan fisik, kebutuhan mental, dan kebutuhan sosial. Teori ini sering membicarakan tentang keamanan, identitas, pengakuan, partisipasi, dan otonomi dalam masyarakat. Sasaran dari teori ini adalah mengidentifikasi dan mengupayakan secara bersama apa saja kebutuhan masyarakat yang tidak terpenuhi agar menghasilkan pilihan dan solusi untuk memenuhi kebutuhan tersebut.

\section{Teori Transformasi Konflik}

Teori ini beranggapan bahwa konflik terjadi karena masalah-masalah ketimpangan, ketidaksetaraan, dan ketidakadilan dalam masyarakat yang muncul sebagai masalah sosial, budaya, dan ekonomi. Konflik ini terlihat dari persaingan dalam kerangka kerja sosial, politik, ekonomi, dan budaya. Sasaran dari teori ini adalah mengubah kerangka dan struktur kerja yang dapat menyebabkan ketidaksetaraan dan ketidakadilan seperti kesenjangan sosial dan ekonomi, meningkatkan hubungan yang terjalin dan sikap jangka panjang antara pihak yang memiliki konflik, dan mengembangkan proses dan sistem sosial, budaya, dan ekonominya.

\section{Teori Negosiasi Prinsip}

Teori ini beranggapan bahwa konflik terjadi karena posisi-posisi yang tidak selaras dan perbedaan pandangan tentang konflik oleh pihak-pihak yang mengalami konflik tersebut. Sasaran dari teori ini adalah membantu pihak-pihak yang berkonflik untuk memisahkan perasaan pribadi dengan berbagai masalah dan isu serta membuat mereka mampu untuk melakukan negosiasi berdasarkan kepentingan mereka daripada posisi 


\begin{tabular}{|c|c|c|c|c|}
\hline JURNAL & \multirow{2}{*}{ VOLUME 3} & NOMOR 1 & HALAMAN 51-64 & $\begin{array}{l}\text { ISSN 2655-8823 }(p) \\
\text { ISSN 2656-1786 (e) }\end{array}$ \\
\hline KOLABORASI RESOLUSI KONFLIK
\end{tabular}

tertentu yang sudah tetap. Lalu melancarkan proses kesepakatan yang menguntungkan kedua belah pihak atau semua pihak yang berkonflik.

Perspektif ini membahas konflik, kekuatan, dominasi, dan ketidaksetaraan dalam konteks abstrak. Perspektif ini berkembang melalui analisis jaringan untuk memahami hubungan antar anggota masyarakat dan untuk menemukan kekuasaan yang dominan dalam masyarakat. Secara tradisional, perspektif ini membahas mengenai institusi dan struktur sosial berskala besar (Tumengkol, 2012). Perspektif ini juga mempelajari kekuasaan dan ketidaksetaraan dalam masyarakat. Oleh karena itu, perspektif ini penting untuk memahami bagaimana dominasi dan penindasan dapat mempengaruhi individu dan menegakkan keadilan sosial.

Artikel ini bertujuan untuk mengetahui dampak dari pengangguran dan penyebab tindakan kriminal. Artikel ini juga ditujukan untuk mengidentifikasi bagaimana pengangguran dapat memicu tindakan kriminal ditinjau dari perspektif konflik yang diharapkan dapat menambah wawasan serta ilmu pengetahuan dan memberikan edukasi kepada masyarakat khususnya para pekerja sosial untuk dapat melaksanakan perannya dalam mengatasi masalah ini dan melakukan pemerataan sumber daya.

\section{METODE PENELITIAN}

Artikel ini ditulis menggunakan metode studi kepustakaan atau literature review dengan merujuk pada hasil pencarian data dan informasi melalui dokumen-dokumen elektronik sebagai referensi untuk mendukung penulisan. Terdapat dua macam sumber data yang digunakan, yaitu sumber primer sebagai referensi yang dijadikan sumber utama dalam penulisan, dan sumber sekunder yang merupakan referensi-referensi untuk mendukung sumber primer. Sumber primer yang digunakan adalah ebook "Dimensions of Human Behavior, Person and
Environment" yang ditulis oleh Elizabeth D. Hutchison. Terdapat juga sumber sekunder berupa artikel-artikel yang membahas tentang topik seputar pengangguran di Indonesia, dampak dari pengangguran, penyebab pengangguran, tindakan kriminal di Indonesia, dampak dari tindakan kriminal, penyebab tindakan kriminal, teori konflik, dan perspektif konflik.

Dengan data yang telah diambil dari berbagai artikel, jurnal, dan situs internet, penulis mencoba untuk meninjau data tersebut dengan perspektif konflik dan mencari korelasi antara pengangguran dengan tindakan kriminal dan dampaknya pada lingkungan masyarakat.

\section{HASIL DAN PEMBAHASAN}

Jenis-Jenis dan Penyebab Pengangguran

Sukirno (dalam Qadrunnada, 2017) menyebutkan bahwa terdapat dua bagian dalam mengidentifikasi jenis-jenis pengangguran, yaitu pengangguran berdasarkan penyebabnya dan pengangguran berdasarkan cirinya. Kedua bagian tersebut masing-masing terbagi kembali menjadi 4 kelompok. Pengangguran berdasarkan penyebabnya terbagi menjadi normal atau friksional, siklikal, struktural, dan teknologi. Pengangguran normal atau friksional hanya sebesar dua atau tiga persen dalam suatu ekonomi, karena ekonomi tersebut dipandang sudah mencapai kesempatan kerja penuh. Pengangguran jenis ini biasanya menganggur karena sedang mencari pekerjaan lain yang dianggap lebih baik. Hal ini terjadi karena pekerjaan yang mudah diperoleh membuat pengusaha sulit mendapatkan pekerja. Dengan begitu, pengusaha menawarkan gaji yang lebih tinggi untuk mendorong para pekerja meninggalkan pekerjaannya yang lama dan mencari pekerjaan baru yang memiliki gaji lebih tinggi atau lebih sesuai dengan keahliannya.

Berbeda dengan pengangguran friksional, pengangguran siklikal terjadi 


\begin{tabular}{|c|c|c|c|c|}
\hline JURNAL & \multirow{2}{*}{ VOLUME 3} & \multirow{2}{*}{ NOMOR 1 } & HALAMAN 51-64 & $\begin{array}{l}\text { ISSN 2655-8823 }(p) \\
\text { ISSN 2656-1786 (e) }\end{array}$ \\
KOLABORASI RESOLUSI KONFLIK & VOLA
\end{tabular}

karena penurunan agregat yang cukup pesat. Penurunan ini dapat disebabkan oleh merosotnya harga-harga komoditas. Kemerosotan ini menyebabkan permintaan produksi pada perusahaan-perusahaan yang bersangkutan mengalami kemerosotan pula. Akhirnya perusahaan-perusahaan mengurangi pekerjanya bahkan menutup perusahaannya karena turunnya permintaan produksi. Mereka yang kehilangan pekerjaannya terpaksa menjadi seorang penganggur.

Mirip dengan pengangguran friksional, pengangguran struktural terjadi karena perusahaan dan industri yang mengalami kemunduran karena tidak dapat terus berkembang maju. Kemunduran ini biasanya terjadi karena kemajuan teknologi yang mengurangi permintaan terhadap suatu barang dan munculnya barang baru yang lebih baik. Biaya yang tinggi membuat perusahaan tidak mampu bersaing dengan perusahaan lainnya. Kemunduran ini menyebabkan kegiatan produksi menurun dan sebagian pekerja terpaksa harus diberhentikan. Oleh karena itu, pengangguran ini disebut struktural karena adanya perubahan struktur kegiatan ekonomi.

Pengangguran berdasarkan penyebabnya yang terakhir adalah pengangguran teknologi. Pengangguran ini disebabkan oleh penggantian tenaga manusia dengan mesin atau teknologi dan bahan kimia lainnya. Kemajuan teknologi membuat kebutuhan akan pekerja dan tenaga manusia semakin berkurang. Dengan begitu, pengangguran semakin bertambah karena tenaga manusia telah tergantikan oleh mesin dan teknologi lainnya.

Pengangguran berdasarkan cirinya terbagi menjadi empat bagian pula, yaitu pengangguran terbuka, tersembunyi, musiman, dan setengah menganggur. Pengangguran terbuka adalah pengangguran yang paling umum terjadi karena lowongan pekerjaan yang tersedia lebih rendah dari banyaknya tenaga kerja yang tersedia. Pengangguran ini juga dapat disebabkan oleh kegiatan ekonomi yang menurun, kemajuan teknologi yang mengurangi penggunaan tenaga kerja manusia, dan terjadinya kemunduran dalam perkembangan suatu industri. Para penganggur jenis ini menganggur secara nyata dan separuh waktu, oleh karena itu dinamakan dengan pengangguran terbuka.

Pengangguran jenis kedua adalah pengangguran tersembunyi. Pengangguran ini umumnya terjadi pada sektor pertanian atau jasa. Pengangguran ini berupa kelebihan tenaga kerja pada suatu kegiatan ekonomi. Contohnya seperti pelayanan restoran yang lebih banyak dari yang diperlukan dan keluarga petani dengan anggota keluarga yang besar mengerjakan suatu lahan dengan luas tanah yang sangat kecil.

Pengangguran musiman juga umumnya terjadi pada sektor pertanian atau perikanan. Pengangguran ini bergantung pada musim dan kondisi alam yang terjadi. Contohnya seperti petani yang tidak dapat mengelola tanahnya karena musim kemarau yang menyebabkan kekeringan. Musim hujan juga membuat para nelayan tidak dapat bekerja karena curah hujan yang tinggi dan ombak laut yang ekstrim. Para petani dan nelayan ini akhirnya terpaksa menganggur selama musim-musim tertentu.

Pengangguran terakhir adalah setengah menganggur. Pengangguran ini biasanya terjadi pada pekerja yang tidak bekerja sepenuh waktu atau jam kerja mereka jauh lebih rendah dari jam kerja normal. Bisa jadi jam kerja yang mereka miliki hanya satu hingga empat jam per harinya atau satu hingga dua hari dalam satu minggu. Mereka inilah yang disebut dengan setengah menganggur atau underemployed. Sedangkan jenis pengangguran ini disebut dengan underemployment.

\section{Dampak Pengangguran yang Memicu Tindakan Kriminal}

Beberapa dampak dari pengangguran yang dapat memicu terjadinya tindakan kriminal dapat dikaji berdasarkan segi-segi 


\begin{tabular}{|c|c|c|c|c|}
\hline JURNAL & \multirow{2}{*}{ VOLUME 3} & NOMOR 1 & HALAMAN 51-64 & $\begin{array}{l}\text { ISSN 2655-8823 }(p) \\
\text { ISSN 2656-1786 (e) }\end{array}$ \\
\hline KOLABORASI RESOLUSI KONFLIK
\end{tabular}

tertentu, seperti dalam segi ekonomi, segi sosial, segi politik, segi keamanan, dan segi individu (Basrowi, et.al, 2018). Dalam segi ekonomi. Pengangguran akan berpengaruh besar terhadap tingkat kemiskinan. Karena pendapatan yang diperoleh seseorang tidak cukup untuk memenuhi kebutuhan hidup sehari-harinya. Hal ini disebabkan karena mereka tidak dapat memperoleh pekerjaan atau sedang tidak melakukan pekerjaan yang dapat menghasilkan pendapatan sehingga mereka menganggur. Karena kebutuhan yang terus berjalan tidak sebanding dengan pendapatan, tidak sedikit dari mereka yang menganggur lebih memilih jalan pintas untuk menghasilkan pendapatan.

Dalam segi sosial, pengangguran dapat menyebabkan seseorang kehilangan aktifitas sehari-harinya. Waktu yang seharusnya digunakan untuk bekerja menjadi terbuang sia-sia karena tidak memiliki pekerjaan. Hal ini membuat mereka tidak percaya diri, putus asa, bahkan depresi. Beberapa penganggur mencari alternatif untuk mengisi waktu luangnya dengan kegiatan yang dapat menghasilkan uang. Mereka bisa saja menjadi pengemis, gelandangan, atau pengamen. Namun terdapat juga sebagian dari mereka yang memilih melakukan tindakan kriminal seperti mencuri, merampok, dan lainnya demi menghasilkan uang yang lebih banyak (Ichsan, 2016).

Dalam segi politik, pengangguran mempengaruhi dunia politik karena dapat menyebabkan maraknya demonstrasi yang terjadi dan membuat dunia politik menjadi tidak stabil (Hia, 2013). Para demonstran tersebut tidak lain adalah para serikat kerja yang tidak mendapatkan dan kehilangan pekerjaannya. Demonstrasi sangat merugikan karena banyak dari demonstran yang melakukan tindakan vandalisme dengan merusak berbagai fasilitas umum (Aminah, 2012). Tindakan vandalisme tersebut termasuk ke dalam tindakan kriminal karena mengganggu ketertiban lingkungan dan merusak fasilitas umum.
Dalam segi keamanan, pengangguran membuat para penganggur melakukan tindakan kriminal demi menghidupi perekonomiannya. Tindakan tersebut seperti merampok, mencuri, perdagangan narkoba, tindakan penipuan, dan lain sebagainya (Basrowi, 2018). Tindakantindakan kriminal tersebut sangat mengancam tingkat keamanan suatu negara dan mengganggu ketenangan masyarakat karena merasa terancam oleh lingkungan tempat tinggalnya sendiri.

Dalam segi individu, menurut Ikawati (2019) pengangguran sangat mengganggu keadaan psikis seseorang. Pengangguran dapat membuat seseorang menjadi kehilangan minat, keterampilan, lebih sensitif (mudah marah, bingung, dan perasaan cemas), depresi, apatis, adanya konsep negatif tentang dirinya sendiri, menarik diri dari lingkungan sosialnya, kehilangan nafsu makan, sulit tidur, mengganggu mobilitas, kreativitas dan produktivitas para penganggur. Dengan segala tekanan yang dialami para penganggur tersebut, mereka menjadi sulit berpikir jernih dalam mencari solusi untuk mendapatkan pekerjaan. Karena kesulitan berpikir tersebut, akhirnya mereka memilih jalan pintas dengan melakukan tindakan kriminal.

\section{Dampak Pengangguran Terhadap Tindakan Kriminal Ditinjau dari Perspektif Konflik}

Dampak dari pengangguran terhadap tindakan kriminal dapat ditinjau lebih lanjut dengan menggunakan perspektif konflik. Seperti yang sudah diuraikan pada pendahuluan, perspektif ini berfokus pada kesenjangan dan akibat dari adanya kelas dalam struktur masyarakat (kelas atas dan kelas bawah) (Tualeka, 2017). Penyebab terjadinya pengangguran tidak lepas dari adanya tindakan dari masyarakat kelas atas yang akhirnya membuat masyarakat kelas bawah tidak memperoleh pekerjaan dan menganggur. Dengan berbagai dampak dari pengangguran yang sudah diuraikan sebelumnya, sebagian dari penganggur 


\begin{tabular}{|c|c|c|c|c|}
\hline JURNAL & \multirow{2}{*}{ VOLUME 3} & NOMOR 1 & HALAMAN 51-64 & $\begin{array}{l}\text { ISSN 2655-8823 }(p) \\
\text { ISSN 2656-1786 (e) }\end{array}$ \\
\hline KOLABORASI RESOLUSI KONFLIK
\end{tabular}

tersebut mencari jalan pintas untuk dapat memenuhi kebutuhan hidupnya dengan melakukan tindakan kriminal. Terdapat tiga teori dari perspektif konflik yang dapat digunakan untuk meninjau dampak pengangguran terhadap tindakan kriminal lebih lanjut.

Teori pertama adalah teori kebutuhan manusia. Teori ini menjelaskan bahwa konflik disebabkan karena tidak terpenuhinya kebutuhan dasar setiap manusia. Manusia dapat memenuhi kebutuhan dasarnya adalah dengan cara bekerja. Dengan pekerjaan yang dimilikinya, manusia dapat menghasilkan uang maupun barang yang nantinya digunakan untuk memenuhi kebutuhan dasarnya (Ismah, 2015). Namun, jika manusia tidak memiliki pekerjaan, maka manusia tidak dapat memenuhi kebutuhan dasarnya dan menganggur. Dengan tidak terpenuhinya kebutuhan dasar tersebut, mereka akan merasa tertekan dan berusaha keras untuk mencari solusi demi memenuhi kebutuhannya (Ikawati, 2019). Dengan tekanan yang cukup berat, akhirnya sebagian dari mereka memilih jalan pintas yang mereka anggap dapat memenuhi kebutuhannya dengan melakukan tindakan kriminal.

Teori kedua adalah teori transformasi konflik. Teori ini menjelaskan tentang ketimpangan, ketidaksetaraan, dan ketidakadilan yang terjadi dalam masyarakat. Terlihat jelas bahwa terdapat ketimpangan antara masyarakat yang bekerja dan masyarakat yang menganggur. Masyarakat merasakan ketidakadilan yang kuat karena tidak semua masyarakat dapat memperoleh pekerjaan yang menunjukkan bahwa semua masyarakat tidaklah setara (Masfiatun, 2019). Masalah-masalah ini akhirnya membuat masyarakat berontak dan melakukan tindakan-tindakan yang melanggar norma dan hukum seperti tindakan kriminal. Sebagian masyarakat melakukan tindakan kriminal agar mereka dapat disetarakan dengan masyarakat lainnya yang memiliki pekerjaan (Rahmalia, et.al, 2019).
Teori terakhir adalah teori negosiasi prinsip. Dijelaskan dalam teori ini bahwa penyebab suatu konflik adalah posisi-posisi yang tidak selaras dan perbedaan pandangan. Hal ini disebabkan oleh perbedaan kepentingan dari pihak-pihak yang berkonflik. Contohnya seperti pengusaha yang berkepentingan untuk melakukan produksi secara efektif dengan menggantikan tenaga manusia oleh tenaga mesin. Pergantian itu membuat banyak pekerja yang kehilangan pekerjaannya dan menganggur karena digantikan oleh mesin (Sukirno dalam Qadrunnada, 2017). Sedangkan para pekerja berkepentingan untuk melakukan pekerjaan agar dapat memenuhi kebutuhannya. Perbedaan kepentingan inilah yang akhirnya menimbulkan konflik diiringi dengan tindakan kriminal. Tindakan kriminal tersebut dapat berupa vandalisme saat melakukan demonstrasi kepada pengusaha, atau sekedar menjadi pencuri sebagai profesinya yang baru.

Dampak dari pengangguran terhadap tindakan kriminal juga dapat ditinjau lebih lanjut menggunakan fokus-fokus dari perspektif konflik. Fokus dari perspektif konflik adalah membahas tentang adanya kekuatan, dominasi, dan ketidaksetaraan yang terjadi dalam masyarakat (Tualeka, 2017).

Konflik yang terjadi sampai saat ini adalah masyarakat yang memiliki kekuatan dan kekuasaan yang tinggi dapat berbuat semaunya dalam menentukan hal-hal penting seperti undang-undang, kebijakan, menentukan siapa yang layak mendapat pekerjaan, dan lainnya (Basrowi, 2018). Hal ini tentu menjadi pertentangan karena dapat membuat banyak masyarakat kehilangan atau tidak mendapat pekerjaan. Contohnya seperti suatu perusahaan yang mengganti tenaga manusia dengan tenaga mesin. Para pekerja terpaksa kehilangan pekerjaannya karena telah digantikan oleh mesin-mesin yang dinilai efektif dan efisien. Hal ini sering terjadi dalam dunia pekerjaan karena perkembangan teknologi yang membuat keahlian manusia sudah 


\begin{tabular}{|c|c|c|c|c|}
\hline $\begin{array}{c}\text { JURNAL } \\
\text { KOLABORASI RESOLUSI KONFLIK }\end{array}$ & \multirow{2}{*}{ VOLUME 3} & \multirow{2}{*}{ NOMOR 1 } & HALAMAN 51-64 & $\begin{array}{l}\text { ISSN 2655-8823 }(p) \\
\text { ISSN 2656-1786 }(e)\end{array}$ \\
\hline
\end{tabular}

tidak dibutuhkan lagi. Mereka yang kehilangan pekerjaannya akan sulit mencari pekerjaan baru karena perusahaan yang lain melakukan hal yang sama. Hal ini dapat memicu para penganggur melakukan tindakan kriminal karena kesulitan dalam mencari pekerjaan baru.

Kekuatan dan kekuasaan yang dimiliki sebagian masyarakat tersebut akhirnya menimbulkan proses dominasi dalam kehidupan masyarakat. Dominasi merupakan proses pengendalian kekuasaan pihak besar (dominan) kepada pihak yang lemah. Dominasi dilakukan untuk tujuan tertentu, sebagian besar karena ekonomi dan kekuasaan (Tumengkol, 2012). Dominasi ini dapat menyebabkan suatu kekerasan dan perpecahan dalam masyarakat. Dominasi ini juga terjadi dalam dunia pekerjaan, seperti perusahaanperusahaan modern yang muncul menggantikan perusahaan-perusahaan tradisional. Perusahaan tradisional akan mengalami kemunduran karena kalah dalam persaingan dengan perusahaanperusahaan baru yang lebih modern. Akhirnya perusahaan-perusahaan tradisional ini bangkrut dan para pekerja di dalamnya kehilangan mata pencahariannya (Hia, 2013). Para pekerja ini akan menganggur sampai mereka mendapat pekerjaan baru. Kemampuan mereka dalam perusahaan tradisional tidak sesuai dengan perusahaan modern dan menyebabkan mereka kesulitan dalam mendapatkan pekerjaan baru. Seiring berjalannya waktu, kemampuan mereka akhirnya hilang karena tidak digunakan namun mereka masih belum juga mendapatkan pekerjaan baru (Probosiwi, 2016). Akhirnya mereka memilih jalan pintas yang termudah yaitu melakukan tindakan kriminal sebagai pekerjaannya yang baru.

Kekuatan dan dominasi dalam masyarakat secara jelas menunjukkan adanya ketidaksetaraan dalam kehidupan masyarakat. Ketidaksetaraan memiliki tiga gagasan utama yang terpisah namun saling berkaitan (Fauziah, 2017). Pertama, gagasan bahwa setiap masyarakat harus memiliki kesempatan yang sama terlepas dari latar belakang, ras, seksualitas, jenis kelamin, dan sebagainya. Kedua adalah pembagian yang adil, bahwa manfaat harus tersebar secara adil dan merata. Ketiga, tentang persamaan hasil yang sama setiap masyarakat tanpa memperdulikan keadaan. Ketidaksetaraan ini juga dapat terlihat dalam dunia pekerjaan. Contohnya seperti kesempatan kerja yang terbatas hanya untuk sebagian masyarakat, pembagian lapangan pekerjaan dan kemajuan peradaban teknologi yang tidak merata. Hal ini menyebabkan masyarakat yang tidak berkesempatan untuk mendapat pekerjaan menjadi menganggur dan mencari jalan lain untuk memenuhi kebutuhannya. Lapangan pekerjaan dan kemajuan teknologi yang tidak merata juga menyebabkan beberapa daerah kekurangan lapangan pekerjaan dan pengangguran semakin bertambah. Bertambahnya pengangguran tersebut seiring dengan bertambahnya tindakan kriminal yang terjadi karena kurangnya lapangan pekerjaan.

\section{Peran Pekerja Sosial dalam Penanganan Pengangguran yang Berdampak Terhadap Tindakan Kriminal}

Pekerja sosial memiliki fungsi untuk membantu masyarakat meningkatkan dan menggunakan kemampuannya secara efektif untuk melaksanakan tugas-tugas kehidupan dan memecahkan masalahmasalah sosial yang mereka alami. Pekerja sosial juga mampu memberikan fasilitasfasilitas kepada masyarakat yang membutuhkan untuk membantunya memecahkan masalahnya. Selain itu pekerja sosial juga mampu mempengaruhi kebijakan sosial yang ada dan memeratakan atau menyalurkan sumber-sumber baik material maupun non material (Asdar, et.al, 2020).

Pekerja sosial memiliki beberapa peranan yang dapat membantu dalam penanganan masalah pengangguran yang berdampak terhadap tindakan kriminal. Menurut Dorang Luhpuri dkk (dalam Hidayah, 2016) peran pekerja sosial yang 


\begin{tabular}{|c|c|c|c|c|}
\hline $\begin{array}{c}\text { JURNAL } \\
\text { KOLABORASI RESOLUSI KONFLIK }\end{array}$ & \multirow{2}{*}{ VOLUME 3} & \multirow{2}{*}{ NOMOR 1 } & HALAMAN 51-64 & $\begin{array}{l}\text { ISSN 2655-8823 }(p) \\
\text { ISSN 2656-1786 }(e)\end{array}$ \\
\hline
\end{tabular}

pertama adalah sebagai pembimbing sosial kelompok. Sebagai pembimbing, pekerja sosial mampu membantu masyarakat dalam mengakses sumber-sumber yang ada, mengidentifikasi masalah yang dihadapi, dan mengembangkan kemampuan masyarakat agar dapat memenuhi kebutuhannya. Dalam hal ini, pekerja sosial mampu mengidentifikasi penyebab terjadinya pengangguran dan tindakan kriminal agar masyarakat mampu menghindari hal-hal tersebut. Salah satu penyebab pengangguran adalah sempitnya lowongan pekerjaan yang tersedia. Dengan begitu pekerja sosial dapat mengembangkan kemampuan dan kreatifitas masyarakat agar dapat memperoleh pekerjaan atau membuka lapangan pekerjaan sendiri. Pekerja sosial juga mampu mengembangkan keahlian masyarakat agar tidak melakukan tindakan kriminal untuk memenuhi kebutuhannya.

Pekerja sosial juga mampu menjadi seorang penghubung (broker). Pengangguran dapat disebabkan karena kurangnya akses dalam mencari lapangan pekerjaan (Basrowi, 2018). Dengan begitu, pekerja sosial mampu menghubungkan masyarakat yang membutuhkan pekerjaan dengan lembaga-lembaga atau perusahaanperusahaan yang membutuhkan dan menyediakan lapangan pekerjaan. Selain itu, pekerja sosial juga mampu menghubungkan masyarakat dengan lembaga-lembaga yang memberikan pelayanan seperti edukasi, pelatihan keterampilan dan keahlian, dan lain sebagainya agar masyarakat terhindar dari pikiran-pikiran yang memicu terjadinya tindakan kriminal.

Peran pekerja sosial lainnya adalah sebagai fasilitator. Pekerja sosial dapat menjadi seorang fasilitator yang memberi dorongan atau membangkitkan semangat kepada masyarakat yang menganggur untuk menggunakan potensi dan sumber yang dimiliki untuk meningkatkan produktivitas dan memenuhi kebutuhan hidupnya. Pekerja sosial juga mampu memberikan dukungan kepada para penganggur untuk memperkuat, mengakui, dan menghargai nilai yang dimiliki oleh para penganggur. Menurut Ikawati (2019) para penganggur membutuhkan dorongan dan dukungan yang kuat dari luar dirinya. Dengan begitu, para penganggur tidak akan merasa tertekan dan mampu berpikir dengan jernih agar terhindar dari pikiranpikiran yang memicu tindakan kriminal.

Peran pekerja sosial yang terakhir adalah sebagai konselor (counselor). Pekerja sosial mampu memberikan layanan konsultasi kepada masyarakat yang ingin mengungkapkan masalahnya (Asdar, et.al, 2020). Dalam hal ini adalah masyarakat yang tidak dapat memperoleh pekerjaan atau menganggur. Pekerja sosial akan mengidentifikasi permasalahannya (pengangguran) serta mengembangkan potensi dan kekuatan yang dimiliki para penganggur. Para penganggur menjadi lebih kompeten dan mampu menemukan alternatif-alternatif dalam memenuhi kebutuhan hidupnya tanpa harus melakukan tindakan kriminal.

\section{KESIMPULAN DAN SARAN Kesimpulan}

Berdasarkan uraian di atas, dapat disimpulkan bahwa pengangguran dapat memicu terjadinya tindakan kriminal. Dampak dari pengangguran dapat ditinjau dalam berbagai segi yang berujung pada tindakan kriminal. Dalam segi ekonomi, pengangguran berdampak langsung pada kemiskinan yang membuat masyarakat tidak dapat memenuhi kebutuhan hidupnya sehingga perlu mencari alternatif lain agar kebutuhannya tetap terpenuhi. Dalam segi sosial, pengangguran membuat masyarakat kehilangan aktifitas sehari-harinya dan membuang waktunya dengan sia-sia tanpa menghasilkan apapun. Dalam segi politik, pengangguran menjadi penyebab maraknya demonstrasi yang diiringi dengan kerusakan-kerusakan dan tindakan kriminal lainnya yang merugikan banyak pihak. Dalam segi keamanan, pengangguran membuat suatu negara menjadi tidak aman karena maraknya tindakan kriminal yang 


\begin{tabular}{|c|c|c|c|c|}
\hline JURNAL & \multirow{2}{*}{ VOLUME 3} & NOMOR 1 & HALAMAN 51-64 & $\begin{array}{l}\text { ISSN 2655-8823 }(p) \\
\text { ISSN 2656-1786 (e) }\end{array}$ \\
\hline KOLABORASI RESOLUSI KONFLIK
\end{tabular}

dilakukan masyarakat demi memenuhi kebutuhan hidupnya. Dalam segi individu, pengangguran memberikan tekanan berat bagi para penganggur yang membuatnya kehilangan keterampilan, percaya diri, depresi, dan lainnya. Dalam segala segi, pengangguran dapat berujung pada tindakan kriminal karena situasi dan kondisi yang membuat seseorang tidak dapat berpikir jernih dan menekan seseorang untuk mencari jalan keluar demi memenuhi kebutuhan hidupnya.

Dampak dari pengangguran terhadap tindakan kriminal juga dapat ditinjau lebih lanjut menggunakan teori-teori dan fokus dari perspektif konflik. Teori kebutuhan manusia menjelaskan bahwa tindakan kriminal dapat terjadi karena kebutuhan manusia yang tidak terpenuhi. Kebutuhan yang tidak terpenuhi ini salah satunya disebabkan oleh pengangguran. Teori transformasi konflik menjelaskan adanya ketimpangan dan ketidakadilan antara masyarakat yang bekerja dan masyarakat yang menganggur. Ketimpangan ini berdampak langsung pada tindakan kriminal karena masyarakat yang menganggur ingin dinilai setara dengan masyarakat yang bekerja. Teori terakhir adalah teori negosiasi prinsip yang menjelaskan tentang perbedaan kepentingan dalam masyarakat. Perbedaan ini menimbulkan pertentangan dan konflik dalam masyarakat sehingga tidak sedikit masyarakat yang melakukan tindakan kriminal demi kepentingannya dalam memenuhi kebutuhan hidupnya.

Fokus dari perspektif konflik ini berhubungan satu sama lain dalam memicu terjadinya tindakan kriminal. Fokus yang pertama adalah adanya kekuatan pada sebagian masyarakat yang menyebabkan terjadinya fokus yang kedua, yaitu dominasi. Dominasi yang terjadi dalam masyarakat secara jelas menunjukkan adanya fokus ketiga, yaitu ketidaksetaraan. Ketiga fokus ini berujung pada pemicu terjadinya tindakan kriminal karena kesempatan dan lapangan kerja yang tersedia sangat terbatas untuk sebagian masyarakat. Sebagian masyarakat lainnya harus mencari jalan lain untuk tetap memenuhi kebutuhannya, dan cara yang termudah tidak lain adalah tindakan kriminal. Oleh karena itu, pengangguran dan kriminalitas menjadi masalah sosial yang sangat serius dan perlu perhatian lebih dari pekerja sosial. Pekerja sosial dapat melaksanakan berbagai perannya dalam menangani masalah ini. Pekerja sosial dapat menjadi perantara para penganggur kepada perusahaan yang membutuhkan pekerja, membantu masyarakat mengidentifikasi masalah yang dihadapinya, mengakses sumber-sumber yang ada dalam membantu masyarakat memecahkan masalahnya, dan memberikan dorongan serta dukungan kepada masyarakat agar tetap semangat dan terhindar dari pikiran negatif yang memicu tindakan kriminal.

\section{Saran}

Berdasarkan tulisan di atas, penulis memberi saran kepada masyarakat untuk memahami bahwa pengangguran memiliki dampak yang luas, tidak hanya kepada para penganggur. Masyarakat harus menyadari bahwa pengangguran tidak hanya disebabkan oleh dirinya sendiri, namun banyak faktor lain diluar dirinya yang dapat menyebabkan pengangguran. Oleh karena itu masyarakat yang menganggur harus memiliki semangat yang besar dan tetap berusaha agar terhindar dari pikiran negatif yang memicu terjadinya tindakan kriminal. Penulis juga menyarankan untuk sebagian masyarakat lainnya agar mampu menghilangkan ketimpangan dan meratakan segala bentuk sumber yang berguna dalam memenuhi kebutuhan masyarakat karena kebutuhan yang tidak terpenuhi sangat mempengaruhi seseorang untuk melakukan tindakan kriminal. Untuk para pekerja sosial disarankan dapat meninjau dan mengatasi masalah ini lebih lanjut sesuai dengan peran-perannya agar masyarakat dapat memenuhi kebutuhannya tanpa melakukan tindakan kriminal. 


\begin{tabular}{|c|c|c|c|c|}
\hline JURNAL & \multirow{2}{*}{ VOLUME 3 } & \multirow{2}{*}{ NOMOR 1 } & HALAMAN 51-64 & $\begin{array}{l}\text { ISSN 2655-8823 }(p) \\
\text { ISSN 2656-1786 }(e)\end{array}$ \\
KOLABORASI RESOLUSI KONFLIK & VOMS \\
\hline
\end{tabular}

DAFTAR PUSTAKA

Aminah, S. (2012). Konstruksi Sosial Kekerasan dan Vandalisme Mahasiswa. Masyarakat, Kebudayaan Dan Politik, 25(2),

139-149.

http://journal.unair.ac.id/downloadfull/ MKP4483-e9b68de503fullabstract.pdf

Anata, F. (2013). Pengaruh Tingkat Pengangguran Terbuka, PDRB perkapita, Jumlah Penduduk dan Indeks Williamson terhadap Tingkat Kriminalitas (Studi Pada 31 Provinsi di Indonesia Tahun 2007-2012). Jurnal Ilmiah.

https://jimfeb.ub.ac.id/index.php/jimfe b/article/view/553

Asdar, M., Roslan, S., \& Tanzil. (2020). Peran Pekerja Sosial dalam Menangani Masalah Sosial Anak. WELVAART: Jurnal Ilmu Kesejahteraan Sosial, 1(1), 1-7.

Basrowi, Yuliana, S., Prayogo, A. D., Liana, J. E., Andriansyah, M., \& Astridinata, I. K. (2018). Pengangguran. Perspektif Teoretis. 114.

BPS. (2019). Statistik Kriminal 2019. Badan Pusat Statistik, 1-218.

Budiarti, R. (2015). Hubungan Antara Persepsi terhadap Kompensasi dengan Kepuasan Kerja Karyawan. Naskah Publikasi

Dermawanti, Hoyyi, A., \& Rusgiyono, A. (2015). Faktor-Faktor yang Mempengaruhi Kriminalitas di Kabupaten Batang Tahun 2013 dengan Analisis Jalur. Jurnal Gaussian.4(2), 247-256.

Desmawati, L., RC, A. R., \& Mulyono, S. E. (2015). Penanggulangan Masyarakat Miskin Kota Rawan Kriminalitas melalui Pemberdayaan Masyarakat di Jalur Pendidikan Nonformal di Kota Semarang. Journal of Nonformal Education, 1(1). https://doi.org/10.15294/jne.v1i1.3986

Fadilah, A. (2016). Komponen Kebutuhan Hidup dalam Regulasi Upah Minimum Perspektif Maqasid Al-Shari'ah. Muslim Heritage, 1(1). https://doi.org/10.21154/muslimheritag e.v1i1.380

Fauziah, N. 2017. Ketidaksetaraan Sosial, Apakah Itu Adil? dalam https://www.kompasiana.com /novianarf/59fe65018325cc30b862158 2/berketidak-setaraan-sosial-apakahitu-adil?page $=$ all $[05 / 11 / 17]$

Gunawijaya, R. (2017). Kebutuhan Manusia dalam Pandangan Ekonomi Kapitalis dan Ekonomi Islam. AlMaslahah, 13(1), 131-150. http://library1.nida.ac.th/termpaper6/sd /2554/19755.pdf

Hia, Y. D. (2013). Strategi dan Kebijakan Pemerintah dalam Menanggulangi Pengangguran. Economica, 1(2), 208213.

https://doi.org/10.22202/economica.20 13.v1.i2.121

Hidayah, N. A. (2016). Pelaksanaan Program Resosialisasi Gelandangan dan Pengemis di Panti Sosial Bina Karya Yogyakarta [Skripsi]. Yogyakarta (ID): Universitas Islam Negeri Sunan Kalijaga Yogyakarta.

Ichsan, P. R. N. (2016). Pengaruh Faktor Sosial Ekonomi terhadap Tingkat Kriminalitas di Provinsi Sumatera Utara [Skripsi]. Surabaya (ID): Universitas Airlangga.

Ikawati. (2019). Dampak Pengangguran Terdidik Ditinjau Dari Segi Fisik, Psikis, Sosial dan Solusinya. Media Informasi Penelitian Kesejahteraan Sosial, 43(1), 1-10.

Ismah, U. (2015). Pengaruh Pengangguran terhadap Kriminalitas di Kabupaten Solok. Kumpulan Artikel Wisudawan S1 Program Studi PPKn Periode Ke 64 Agustus 2015, 4(9).

Khairani, R., \& Ariesa, Y. (2019). Analisis Faktor-Faktor Yang Mempengaruhi Tingkat Kriminalitas Sumatera Utara (Pendekatan Ekonomi). Jurnal Kajian Ekonomi Dan Kebijakan Publik, 4(2), 99-110.

Kosmaryati, Handayani, C. A., Isfahani, R. N., \& Widodo, E. (2019). Faktor-Faktor 


\begin{tabular}{|c|c|c|c|c|}
\hline JURNAL & \multirow{2}{*}{ VOLUME 3 } & \multirow{2}{*}{ NOMOR 1 } & HALAMAN 51-64 & $\begin{array}{l}\text { ISSN 2655-8823 }(p) \\
\text { ISSN 2656-1786 }(e)\end{array}$ \\
KOLABORASI RESOLUSI KONFLIK & VOMS \\
\hline
\end{tabular}

yang Mempengaruhi Kriminalitas di Indonesia Tahun 2011-2016 dengan Regresi Data Panel. Indonesian Journal of Applied Statistics, 2(1), 10-20. https://doi.org/10.13057/ijas.v2i1.2793 2

Masfiatun. (2019). Pengaruh Faktor Ekonomi terhadap Jumlah Kejahatan (Crime Total) di Indonesia (20152017). Jurnal Keamanan Nasional, $5(2)$, 89. https://doi.org/10.31599/jkn.v5i2.437

Nadilla, U., \& Farlian, T. (2018). Pengaruh PDRB Perkapita, Pendidikan, Pengangguran, dan Jumlah Polisi Terhadap Angka Kriminalitas di Provinsi Aceh. Jurnal Ilmiah Mahasiswa, 3(1), 110-118.

Nasional.kompas.com. 2012. Kapolda Metro Jaya: Kriminalitas Akibat Pengangguran.

https://nasional.kompas.com/read/2012 /11/21/15151119/kapolda.metro.jaya.k riminalitas.akibat.pengangguran [21/11/12]

Prayetno. (2013). Kausalitas Kemiskinan terhadap Perbuatan Kriminal (Pencurian). Media Komunikasi FIS, 12(1), 30-45.

Probosiwi, R. (2016). Pengangguran dan Pengaruhnya terhadap Tingkat Kemiskinan. Jurnal PKS, 15(2), 89100.

Purwanti, E. Y., \& Widyaningsih, E. (2019). Analisis Faktor Ekonomi yang Mempengaruhi Kriminalitas di Jawa Timur. Jurnal Ekonomi-QU, 9(2), 154177.

Pustakabergerak.id. 2020. PerspektifPerspektif dalam Sosiologi. https://pustakabergerak.id/artikel/persp ektif-perspektif-dalam-sosiologi [22/07/20]

Qadrunnada, L. (2017). Analisis Pengaruh Pendidikan Pertumbuhan Ekonomi dan Rasio Gini terhadap Tingkat Pengangguran Terbuka di Daerah Istimewa Yogyakarta Tahun 2010-2015 [Skripsi]. Yogyakarta (ID): Universitas Muhammadiyah Yogyakarta.
Rahmalia, S., Ariusni, \& Triani, M. (2019). Pengaruh Tingkat Pendidikan, Pengangguran, dan Kemiskinan terhadap Kriminalitas di Indonesia. Jurnal Kajian Ekonomi Dan Pembangunan, 1(1), 21-36.

Rusnani. (2015). Pengaruh Kemiskinan terhadap Meningkatnya Kriminalitas di Kabupaten Sumenep. PERFORMANCE “ Jurnal Bisnis \& Akuntansi," 5(1), 42-59. https://doi.org/10.24929/feb.v5i1.128

Salamadian.com. 2018. Pengangguran: Pengertian, Penyebab, dan Jenis-Jenis Pengangguran.

https://salamadian.com/pengertianjenis-jenis-pengangguran/ [21/12/18]

Sampit.prokal.co. 2020. Pengangguran Meningkat, Kriminalitas Bisa Melonjak.

https://sampit.prokal.co/read/news/280

43-pengangguran-meningkat-

kriminalitas-bisa-melonjak.html [14/04/20]

Sari, N. J. (2019). Analisis Pengaruh Tingkat Pengangguran dan Kemiskinan Terhadap Tingkat Kriminalitas di Kecamatan Jabung, Lampung Timur Ditinjau dari Nilai-Nilai Ajaran Islam [Skripsi]. Lampung (ID): Universitas Islam Negeri Raden Intan Lampung.

Sari, R. I. (2018). Hubungan Pengangguran, Pendidikan dan Distribusi Pendapatan terhadap Angka Kriminalitas di Sulawesi Selatan Menggunakan Analisis Regresi Data Panel [Skripsi]. Makassar (ID): Universitas Islam Negeri Alauddin Makassar.

Shahar, I. S. (2018). Analisis Determinan yang Mempengaruhi Kriminalitas Provinsi Lampung Tahun 2009-2015. http://repository.umy.ac.id/handle/123 $\underline{456789 / 19650}$

Tualeka, M. W. N. (2017). Teori Konflik Sosiologi Klasik dan Modern. AlHikmah, 3(1), 32-48. http://journal.umsurabaya.ac.id/index.php/Ah/article/vie $\underline{\mathrm{w} / 409}$ 


\begin{tabular}{|c|c|c|c|c|}
\hline JURNAL & \multirow{2}{*}{ NOLUME 3} & NOMOR 1 & HALAMAN 51-64 & $\begin{array}{l}\text { ISSN 2655-8823 }(p) \\
\text { ISSN 2656-1786 }(e)\end{array}$ \\
\hline
\end{tabular}

Tumengkol, S. M. (2012). Teori Sosiologi Suatu Perspektif Tentang Teori Konflik dalam Masyarakat Industri. http://repo.unsrat.ac.id/627/1/KARYA ILMIAH_TUMENGKOL6.pdf 